European journal of American studies

Summer 2017, including Special Issue: Popularizing

Politics: The 2016 U.S. Presidential Election

The Fight to Bear Arms: Challenging the Second Amendment and the U.S. Constitution as a Sacred Text

John McNamara

CpenEdition

Electronic version

URL: https://journals.openedition.org/ejas/12179

DOI: $10.4000 /$ ejas. 12179

ISSN: $1991-9336$

Publisher

European Association for American Studies

Electronic reference

John McNamara, "The Fight to Bear Arms: Challenging the Second Amendment and the U.S.

Constitution as a Sacred Text", European journal of American studies [Online], 12-2 | 2017, document 15, Online since 01 August 2017, connection on 08 July 2021. URL: http://journals.openedition.org/ejas/ 12179 ; DOI: https://doi.org/10.4000/ejas. 12179

This text was automatically generated on 8 July 2021.

Creative Commons License 


\title{
The Fight to Bear Arms: Challenging the Second Amendment and the U.S. Constitution as a Sacred Text
}

\author{
John McNamara
}

\section{Law}

1 One of the most contentious issues that persists in American life today is the constitutional right to personally own and possess firearms. The Second Amendment of the Constitution of the United States guarantees citizens of the nation this right through a single sentence which states that "A well regulated Militia, being necessary to the security of a free State, the right of the people to keep and bear Arms, shall not be infringed."

Controversy surrounding this amendment is ongoing and individual political standpoints on this issue tend to denote the broad political allegiance of individuals as well as local and municipal districts. The Second Amendment and the enmity that it arouses has seen it endure only limited testing in the Supreme Court. Challenges to this amendment are seen in some quarters as a challenge to cherished individual freedom itself and as a consequence invoke a great deal of public indignation. Quite apart from the practical need to possess firearms in the nouveau frontier nation that was eighteenth century America, the essence of this right rests on the view that an armed populace could not and would not be subjugated. It existed (and exists) as a final bulwark against the spectre of tyranny. It ensured that the individual citizen could always keep an unjust regime or civil threat at bay through that citizen's feasible potential to resort to violent dissent on their very threshold. All efforts to dilute this right are perceived in many quarters as a direct attack on the sovereignty of the individual and an effort to subjugate or neutralise the masses.

3 Second Amendment rights are jealously guarded and their protection is the focus of powerful Washington lobby groups as well as very vocal, civil libertarian associations 
such as the National Rifle Association. The Second Amendment furnishes America with not just one of the most hotly debated lines in the United States' canon of law but also a classic case of eighteenth century logic uncomfortably co-existing with twenty-first century reality and sensibility. The United States of the late eighteenth century had a number of practical realities that had to be considered. Firstly, firearms were a practical imperative from both a private and commercial point of view. There was the threat of the lawless element of a frontier society, of invasion from abroad or 'insurrection' by Native Americans or the enslaved African-American populace as well as the very real and present danger of wild animals. These were all seen to necessitate personal protection. Also, hunting supplemented dietary requirements and was practised as a commercial pursuit. Secondly, the Second Amendment ensured a measure of personal autonomy within the new Federal State. It was an insurance policy that ensured if the polling booth was to fail to yield a satisfactory and equitable society (or was suspended entirely), a popular uprising could not be prevented through a federal monopoly over weaponry. It was a practical law that would ensure good order and deter the temptation toward the path of tyranny by any subsequent federal government. The population could rest assured that if they, or their descendants, were ever to realise absolute exasperation with their government, it was their right - and (potentially at least) a practical possibility - to overthrow such a regime. This idea tallied with John Locke's thesis that legitimised revolution in extraordinary circumstances of oppression or injustice as had been the Founding Fathers' justification for war with the British and eventual independence. It was thought that a nation with a facility such as this could never be subjugated or oppressed.

The United States is no longer a frontier society or a novel, experimental democracy. Many of the practical everyday reasons that motivated the Second Amendment are no longer relevant. In a twenty-first century America - many of the original concerns could, potentially at least, be construed as archaic or perhaps, hyper-vigilant. This consideration is combined with the technological evolution of firearms and the problematic nature of delimiting, in this technologically advanced era, what constitutes 'arms' and what it is to 'bear' them. Are tactical nuclear weapons 'arms' in the sense that the framers of the Second Amendment envisioned them? Should one be entitled to 'bear' a bazooka? In answering this question the efficacy of the weapon in its intended purpose seems to be a less relevant factor than the manner of its conveyance. A previous Supreme Court judgement has delimited what is meant by 'arms' and what it is to 'bear' them (United States v. Miller, 1939). The Supreme Court recognised conventional firearms as being appropriate to the term 'arms' and therefore recognises all the ballistic descendants of the standard eighteenth century musket as being appropriate to this category. One is, therefore, entitled to 'keep' and 'bear' such a weapon in accordance with their constitutional rights, for the purposes of recreation or self-defence. Rapid firing semi-automatic rifles have been deemed to be appropriate to this category of weapon even though their rate of fire exceeds their technological antecedents by a factor of (conservatively) twenty or more.

In the United States there are approximately thirty-three thousand gunshot fatalities per annum. Roughly $95 \%$ of these fall into the category of either homicide or suicide. The remaining $5 \%$ is divided between fatalities which are classified as 'accidental' or a smaller number that are deemed to fall under the category of 'lawful' (or 'justifiable') homicide. The majority of 'justifiable' homicides are the result of 'legal intervention' by law enforcement agencies as opposed to private citizen ${ }^{\mathrm{ii}}$. This begs the question, 
especially it must be said from a European perspective, why is the Second Amendment so fervently guarded from interference or limitation? How - especially in the context of contemporary American society where the firearm has become so synonymous with crime, suicide and random massacres perpetrated by psychotics and terrorists - can the Second Amendment elicit the support that it has and remain entirely unaltered? It is a hugely divisive issue in which social and technological reality is pitted against political inheritance. The terms through which these rights are afforded through this amendment are hotly debated and the fact remains, that the rule of law is final, that the law in its original terms is paramount and any attempt to dilute or amend the words incarnate of the fathers and authors of the national inheritance (Founding Fathers) is a momentous and highly contentious task.

\section{District of Columbia v Heller (2008)}

6 The Supreme Court case of the District of Colombia v Heller (2008) exemplifies the parameters of this debate and also highlights the focus on the hermeneutical examination of the original text and its meaning. The fact that roughly half of Americans favour controls or limitations on the ownership of firearms is not reflected in Supreme Court decisions on the Second Amendment ( $46-55 \%$ respondents depending on the question asked \& the investigating body/polling company) ${ }^{i i i}$. If we accept for a moment that the majority of the American populace favours gun control (as Gallup currently suggests and most polls suggested at the time of DC v Heller in 2008) - this case counters prevailing attitudes to this issue. It rests as a classic example of the 'tyranny of the majority' (as envisaged by Tocqueville who popularised the phrase) being thwarted by due process, the rule of law and a Supreme Court judiciary's absolute devotion to the literal text of the Constitution and its Amendments ${ }^{\text {iv }}$. The Court's decision rested almost solely on their interpretation of the single line that is the Second Amendment. In the case of D.C. v Heller, a local law in Washington D.C. that had regulated the ownership of firearms (especially handguns) was constitutionally challenged under the provisions of that amendment. This local law in Washington D.C. (which was typical of many municipal districts in the United States) ensured (in summary) that the registration of handguns was restricted and that firearms kept in the home were to be either disassembled or have their triggers locked with a specialised locking mechanism. The court found this municipal law to be unconstitutional and contrary to Second Amendment rights.

7 Precedent with regard to the Second Amendment is relatively limited so this case focussed overwhelmingly on the substance of the text of the amendment. If the court found in favour of Heller's petition and struck down the D.C. law - it would place firearms restrictions all over the United States in constitutional peril. The opinion of the court, delivered by Justice Antonin Scalia, began its assessment of the issue at hand by explicating the terms through which the amendment was to be assessed. Justice Scalia outlined the semantic context in the following terms:

The Second Amendment is divided into two parts; its prefatory clause and its operative clause. The former does not limit the latter grammatically, but rather announces a purpose......Although the structure of the Second Amendment is unique in our Constitution, other legal documents of the founding era, particularly individual-rights provisions of State Constitutions, commonly included a prefatory statement of purpose. Therefore, while we will begin our textual analysis with the 
operative clause, we will return to the prefatory clause to ensure that our reading of the operative clause is consistent with the announced purpose. ${ }^{v}$ The function of constitutional courts everywhere is to debate the letter of the law and to pass judgement as appropriate. The difference with the United States and the textual analysis endemic to US constitutional law is that that law is hallowed and nationally revered. It is perceived and acknowledged as a political inheritance from the allknowing, near infallible composers of that law. This loyalty to the letter of the law, the relative immunity of that law from change or modification, combined with the very prevalent ruminations on the exact intent of the Framers or even speculation as to what might have been their opinion on a current legal conundrum - suggests more than a simple loyalty to the letter of the law and its practical implementation. It suggests something beyond that, approaching a type of civil devotion to the heroic initiators of the nation. ${ }^{\mathrm{vi}}$

The opinion of the court in the case of D.C. v Heller, in its assessment of the operative clause of the Second Amendment, seeks to forensically examine the words employed and their meanings. The word 'arms' is defined with reference to eighteenth and nineteenth century dictionaries and is found to have much the same meaning as it does today ${ }^{\text {vi }}$. This is also the case with the relevant verbs to 'keep' and to 'bear'. However, the court found that the phrase to 'bear arms' was not limited to military service or attachment to a militia.

From our review of founding-era sources, we conclude that this natural meaning was also the meaning that 'bear arms' had in the 18th century. In numerous instances, 'bear arms' was unambiguously used to refer to the carrying of weapons outside of an organised militia. The most prominent examples are those most relevant to the Second Amendment: Nine state constitutional provisions written in the 18th century or the first two decades of the 19th, which enshrined a right of citizens to 'bear arms in defence of themselves and the state'.... It is clear from those formulations that 'bear arms' did not refer only to carrying a weapon in an organised military unit. viii

The focus is on context. The context in which the words were composed is paramount and an exact understanding of the implications of their meaning is sought. The original context trumps any pretence toward a reflection on contemporary conditions and the court restricts itself to interpreting eighteenth century logic and motivation.

The Phrase 'bear arms' also had at the time of the founding an idiomatic meaning that was significantly different from its natural meaning: 'to serve as a soldier, to do military service, fight' or 'to wage war.' But it unequivocally bore that meaning only when followed by the preposition 'against' which in turn was followed by the target of the hostilities. ${ }^{\text {ix }}$

The Justices have assumed a theological/hermeneutical role in relation to constitutional law. Theirs' is a task in which they must decipher the intent of the Framers of the constitution, the nation's 'Founding Fathers'. They must explicate what these intentions were and seek to apply them to contemporary society. Constitutional law in the United States is conducted on the assumption that all constitutional issues can be resolved through a conclusive hermeneutical interpretation of the letter of the law through which the most equitable and politically expedient resolution can be divined. We see this here with this semantic dissection of the single sentence that incorporates the Second Amendment. The Constitution represents the blueprint for freedom, liberty and all the other basic elements of the 'American Creed' while also 
demonstrating the limits and scope of these basic founding principles. A true America is beholden to this framework through which it was conceived as a nation.

This case is also typical in its references to the architects of the Constitution and the nation. James Madison, Thomas Jefferson, Samuel Adams and other such historical luminaries are mentioned through the course of the opinion of the court in this case. ${ }^{x}$ References to these national heroes and their private notes, annotations and drafts of the Constitution and other founding documents, are thought to offer key insights into the exact motivations and intentions of the framers of the Constitution and the other Founding Fathers. In the course of the legal archaeology that is U.S. Constitutional law, minute details amongst the private papers or public statements of the Founding Fathers provide clues and yield critical insight into the exact intentions of these revered national heroes of the initiation of the nation. James Madison's original draft of the Second Amendment included a 'conscientious objector clause' that followed the text of the final draft with an additional clause which stated "...but no person religiously scrupulous of bearing arms, shall be compelled to render military service in

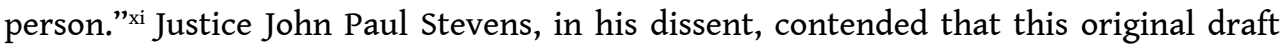
betrayed the fact that Madison's intention in relation to the right to bear arms was inextricably linked to service in a militia at the behest of the federal state and was therefore a matter for military expedience rather than a personal and absolute right to possess firearms. This original clause, which was designed to facilitate the pacifist Quaker population resident in the United States, is used as current evidential support for a specific idea of what a key framer of the Constitution's precise intentions were. Justices Scalia and Stevens argue and counter-argue over this provision that only ever reached the draft stage. This argument over a provision that would only ever be hypothetically included in the amendment demonstrates the gravitas of the most thoughtful ruminations or, conversely, the merest whims of the Framers of the Constitution. The Constitution rests as a body of law and the culmination of an existential and political consideration of the rights of the citizen and the operation of the government that was to oversee his/her welfare by men who came to be regarded as the heroic and ingenious 'fathers' of the nation. Their official words enshrined in the Constitution or, equally, their personal or temporary drafts, ruminations or conjecture have become sacrosanct and carry a weight unmatched in a contemporary context.

13 Justice Scalia countered Justice Stevens' argument by demonstrating that the Quaker exemption was an exemption from military service alone, it was a separate issue and in no way had any bearing on the right to bear arms in a general sense. This inquiry into the exact motives of the political ancestors of the nation continues with a speculative examination of what Thomas Jefferson would have thought about the matter. Jefferson, whilst drafting of the Constitution of the State of Virginia (which pre-dated the Federal Constitution), proposed the clause "No Freeman shall be debarred the use of arms within his own lands or tenements." ${ }^{\text {xii }}$ His proposed draft was omitted. The fact that Jefferson was away at the time of the composition of the Federal Constitution preoccupied as he was in his role as ambassador to France - does not inhibit the Supreme Court from including in their consideration, Jefferson's clear endorsement (on, at least, that occasion) of free and unimpeded ownership of firearms. Jefferson's endorsement of the right, through a proposed clause in a separate constitution, lends weight to the argument and the finding of the court in support of Second Amendment rights. 

constitution (Massachusetts), made explicit his alleged support for personal ownership as opposed to ownership being tied exclusively to service in a militia ${ }^{\text {xiii }}$. This was also raised as evidential support for Second Amendment rights. The political inheritance of the nation is embodied in the ones who codified the nation's elementary rights and design of government. The laws they enshrined and even the drafts that were proposed to be included in those laws but were ultimately rejected, colour contemporary decisions in a manner that is unmatched in any other Western democracy. The ideas that they enshrined at the point of their quills pervade fundamental ideological questions that are faced by the technologically advanced, globalised America of today. The Constitution is canonical and absolute. Interpretations of the hallowed text are, however, simultaneously beholden to the personal philosophies and political opinions of the heroic and ingenious patriarchy that composed the document and instigated the nation.

The hermeneutic and eschatological deciphering continues with an examination of contemporary public discourse and interpretations of the Constitution as well as established political philosophy and political inheritance of the day that undoubtedly coloured the existential predisposition of the framers of the document. In his delivery of the opinion of the court Justice Scalia quotes a roughly contemporary debate in the House of Lords at Westminster in which a certain Lord Richmond

...described an order to disarm private citizens (not militia members) as 'a violation of the constitutional right of Protestant subjects to keep and bear arms for their own defence'. In response, another member of Parliament referred to 'the right of bearing arms for personal defence' making clear that no special meaning for 'keep and bear arms' was intended in the discussion. ${ }^{\text {xiv }}$

The separate trajectory of English (later British) law regarding firearms is, of course, entirely arbitrary at this point. What is key to the argument is a contemporary interpretation of a mutual linguistic and political inheritance that is exemplified by these quotations. There is also an acknowledgement that this law was of the same legalistic lineage, namely the Act of Succession (1689) and the English Bill of Rights, and the key point is that these quotations help to delimit the exact meaning of the short phrase that is the Second Amendment. Justice Scalia engages in an extensive forensic dissection of seventeenth and eighteenth century English law and political discourse to further explicate the exact motivations behind the amendment. His focus was the issue of whether or not the Second Amendment was solely intended to facilitate the mobilisation of a militia or, was it in fact, to guarantee the personal right to possess firearms - as was ultimately concluded by a majority opinion of the court. To this end, the Game Act of 1671 is analysed in terms of how the Stuart monarchies attempted to restrict access to firearms by individual citizens and the English Bill of Rights is held as a direct response to what was perceived of as the threat of the Stuart regime to this established civil liberty. In an analysis of the English canon of law of the era preceding the U.S. Constitution and Bill of Rights, an attempt is made to prove that the individual right to bear arms was foremost in the minds of the composers of this ancestral law to the American version. Further to this, William Blackstone who was a professor of law in England roughly at the time of the composition of the U.S. Constitution is referred to on numerous occasions through the course of the opinion of the court. Blackstone's 'Commentaries on the Laws of England' is considered a classic interpretation of Common Law and is relied on heavily by the court in order to ascertain a precise 
interpretation of the American version that the English canon of law had inadvertently contrived to initiate. US Constitutional law is inevitably conscious of the exact law as inherited. Beyond this, it takes cognisance of the political temperament and philosophy of those who composed that law as well as the political inheritance of that era which served to shape that law. The court engages in a type of eschatological, seculartheological inquiry in which the gospel of the nation is deciphered and solutions to social and political problems are divined through the hallowed words of the text and speculative analysis of the precise intentions of its authors.

17 In a chapter that analyses the 'Golden Age' of nations in Anthony D. Smith's Chosen Peoples, Smith describes heroic ages and nascent epoch of the nation as follows:

Heroic and creative types of golden age often coexist in the same cultural community as cultural resources and as sacred pasts. Both can be used for purposes of legitimation and mobilization, but they may also be held in respect, even reverence, setting a standard that is hard to equal, let alone surpass. ${ }^{\mathrm{xv}}$

It is doubtless that America's Founding Fathers have 'set a standard' in this context and this fact is very obviously demonstrated by the reverence exhibited for the words of their political bequest to the nation. Of course, the US Supreme Court will resort to jurisprudence and regularly does. Equally the other branches of government will seek to advance or evolve the law according to the standards of the day or what's typically termed 'evolving standards of decency'. In that sense there is a very real effort to 'surpass' the 'golden age'. However, all of this typically transpires in the context of estimating all political and legal action in the context of its constitutionality and therefore its validity in relation to the key terms set by the founders.

19 Michael Billig conceives of nationalism as persisting in the mundane, in institutional practice and beyond the fervour of nation building. He sees nationalism as equally prevalent in the institutional practices of established western nations as it is in the caldron of conflict and active struggle of nascent nations. The US Supreme Court's routine deference to the authors of the US Constitution and Bill of Rights conforms to what Billig would conceive of as an 'unflagged' habitual expression of the nation's core ideology and communal values ${ }^{\mathrm{xvi}}$.

This dormant nationalism of the established nation is continuously reinforced. Billig utilises the verb 'flag' in order to demonstrate how nationalism is hugely endemic in more established nations albeit in a more subtle manner. The flag of the developing nationality, accompanied as it is so often, with a banner of protest or threat of violence is an overt 'flagging' of nationhood in support of the nationalist cause or struggle. The routine display of a flag in the established nation is an 'unflagged' nationalistic ritual. It is 'banal' in that it is unexceptional and uncontested. It is through this accepted status that it melts into the background and continues to exist in the everyday fabric of society. Billig's use of the term 'flagging' encompasses all of the subtle reminders of nationhood. He describes how the nation is 'flagged' continuously and during the course of the most ordinary, everyday events including the practice of law and jurisprudence. Billig regards this as a subtle reinforcement of the nation, positioning the nation's undoubted sovereignty as a most fundamental, given, fact of life in the minds of its citizenry. Equally, it could be argued, it serves to ingrain national ethos, delimit absolutes for that nation and identify the exemplary, the ideal type, the national hero and works to expound his/her/their values or perceived values. This conception of what constitutes nationalism is seen by Billig to exempt established 
nations from treatments that analyse their everyday, ordinary, 'banal' nationalisms. The subtle nationalism of the nation that is without a political cause or threat is lost to the spectacle of violent insurrection and the drama of the rhetoric of the freedomfighter, terrorist, neo-fascist, or any exponent of the underdeveloped or unrequited nationalist cause.

21 Following Billig's model of banal, ingrained nationalism, the essence of American nationalism emerges in the narrative of its inception and the institutional reverence for that formative era and the key characters that played a role in the birth of the nation. Radical in its conception, novel in its nature and scope, benevolent in its intent, the foundation of the United States exists for Americans as a permanent template for nationhood. It exists as the ideal moment in time and space. A perennial reminder. The parameters of governance and the ideology that is enshrined in the founding documents resulted in national devotion to the heroic characters that oversaw and implemented independence. National regard for the events of that era and the heroic characters of the narrative of independence are imperative to the inculcation of what is perceived of as the essential America and the Volksgeist of that nation as well as the practical workings of key institutions of state such as the Supreme Court.

America is exemplified by the aspirations of that time. It is in this regard that a most banal volksgeist emerges. The United States, through its origins, represents 'Liberty', 'Justice' and a myriad of other positive aspirations that fly in the face of tyranny and oppression. The manner in which organs of the state such as the Supreme Court harbour an institutional reverence for the figures of this era illustrates - for the nation - the foresight of the founders' actions. This combined with the continuing success of the adoption and maintenance of their ideological departures lends immeasurable gravitas. Their actions are considered providential and vindicated through the flourishing of successive generations that ascribed to the original vision of the nation. They reside as heroes in the nation's history and are seen to typify all that is positive about the United States. This represents a communal acceptance of a given fact, a largely indisputable historical precedent that the nation is expected to remain faithful to. Within Billig's framework this fulfils the criteria of banal nationalism as observed throughout the western world. It contains all the trappings of a banal nationalism in that there is a perceived inherent superiority of the domestic political and ideological inheritance, and it is through this convention that it is transmitted through the generations as a noble and distinct departure. It is also uncontested, a given, taken for granted as it is and exists on the periphery of the conscious mind as a pillar of national self-perception.

\section{A Sacred Text}

Constitutional law throughout the world is invariably subject to semantic dissection as is practised in the United States. As law is codified and continuously interpreted a reevaluation of the text that embodies that law is unavoidable - especially as novel legal circumstances arise. The United States and its Constitution is unique however in that constitutional law in that country moves beyond simple semantics and into the realm of what can only be called hermeneutics. Nowhere else are the intentions and personal philosophies of those that composed the law more readily assessed and debated. The analysis of the Constitution does not stop at the technical reality of language. It moves 
beyond this. It extends to the motivations and political inheritance of the framers of the document and even into the realm of speculation as to what they would perceive of a current legal conundrum. In this context, law is a cultural and political inheritance. It is a template through which correct action is to be forensically sought as the text itself endures - perceived as it is as an infallible guide to the operation of a society edging it ever closer to a sort of projected utopian perfection. In essence, all the clues to ideal and correct living are seen to be encoded between its lines and it is up to the contemporary generation to ensure that a legal and often, through that, a political exegesis is to be extracted in order to ensure a more satisfactory society.

This kind of institutionalised devotion to the words of the initiators of a communal group (the nation) is a characteristic of religious devotion and adherence. Likewise, the hermeneutic exercise is one that is, of course, inherited from Biblical inquiry and the struggle to provide a precise guide for the conduct of a truly Christian life through a precise scholarly interpretation of the word of God. Hermeneutics, therefore, entails the theory and methodology of interpretation of an established text (traditionally Scripture). In theology, hermeneutics denotes the method through which Biblical exegesis is achieved. It is through this that it is thought that the secrets of a good and righteous life will be unlocked. The method of the Supreme Court is hermeneutical in the sense that it dissects the text of the document in the traditional manner of hermeneutical inquiry that sought to decode 'truth' and meaning from divinely inspired texts. The Supreme Court seeks to extrapolate fundamental meaning from a secular equivalent in a civil setting with the goal of administering and preserving justice. It seeks to identify the manner in which the essential American nationalist philosophy was conceived and ensures that it continues to be propagated through this hallowed document and contemporary interpretations of it. It remains faithful to the archetypal model of America that was constitutionally cast in the wake of its successful revolution.

The Reformation is recognised as the source of modern hermeneutics. The translation of the Bible into the vernacular, the theological arguments that ensued as well as the questioning of religious dogma, all hastened the necessity of a more clinical and interpretive brand of biblical scholarship. Harvie Ferguson points to the fact that the continuous problems with translation and contextualisation made apparent the fact '... no text could, in fact speak for itself..., ${ }^{\text {xvi }}$ no more so than when conflicting translations and contextualisations were emerging unabated. The narratives, events and types of experiences that the Bible sought to convey were inevitably compromised and in many instances, related in a contradictory manner. Exact meaning was, inevitably, elusive. The use of hermeneutics to define and 'divine' the meaning of scripture was a reflection the autonomous culture of Protestant biblical scholarship in general and the rejection of dogmatic religious authority with its monopoly of interpretation of the word of God. The Reformation bred this questioning analysis of scripture and through that a similar analysis of all textual testament as the written (or more pertinently, the printed) word became the cornerstone of Western civilisation. Harvie Ferguson puts it best with the following contention:

This view is readily generalizable to all texts and, as in modernity all reality can be viewed as representations, everything that appears externally to be given as a world is best understood textually. All human activity is a process of active interpretation of the world in which it finds itself and which forms its arena. 
Hermeneutics is just the methodological implication of modernity as human selfactivity; as the declaration of autonomy in which modernity is inaugurated. ${ }^{\text {xviii }}$ history in the human appraisal of the world that surrounds us led him to explore how the world of science and philosophy is influenced by this human consciousness of how the world is historically and socially constructed through cumulative knowledge acquired and modified through the ages. This '...totality of human existence through reflection...' ${ }^{x x}$ that emerged through the ages, furnishes us with a body of knowledge, that is historically constructed and so, colours our perception of what is current (e.g. the right to own and possess a firearm conceived of as a sacred political inheritance). Dilthey's historical rationale provided a framework with which to assess the objectification of what he called the 'human spirit'. Dilthey sought to provide specific examples of this objectification in action and did so through an assessment of various arenas of human endeavour including hermeneutics itself. He believed that our historical understanding was critical in our assessment of all action and circumstances. Concrete manifestations of the transcendental human spirit and references to it are imperative to our approach to all the elementary questions and novel scenarios that greet the communal group. The hermeneutical enterprise exists then as a rudimentary of human existence and a cornerstone of civilisation, manifesting itself in the most profound fashion as the goals and norms of society are questioned or contested in many arenas - not least of which being the law.

Paul Ricoeur takes up this theme from Dilthey and stresses the importance of the Western tradition of narrative and textuality. Ricoeur engaged in a broad examination of the nature of consciousness and perception in the Western World throughout history. He sought to decipher the nature of our consciousness of this world and how humanity 'interprets' the new and as yet undefined throughout the course of history. His preoccupation is the manner of interpretation and the nature of the development of knowledge or standards for human behaviour. This is surveyed through an acknowledgement that the sum of human knowledge and perception 'transcends consciousness' or lives beyond singular perception. In short, we are a product of the 
world that we inherited and the hermeneuticism of many generations. However, Ricoeur maintains that in reality, this transcendental spirit does not detract from the fact that all that is transcendent is constituted in the conscious mind in order to be maintained and quantified. The mysterious, transcendental spirit has to be located and comprehended through what is an ultimately hermeneutic undertaking that seeks to define what is abstract and evasive. Ricoeur pointed to human fault and the hermeneutic preoccupation with defining what is evil, sinful or profane as was the original focal point of hermeneutics. ${ }^{x i}$ Harvie Ferguson outlines Ricoeur's assessment of the implications of this hermeneutic focus on human fault:

From defilement, through sin, to evil, the incomprehensible, as well as the transparently meaningful, has a cultural history and hermeneutics includes both in a developing and dynamic interrelation. Where hermeneutics began in a critical examination of the sacred text, it has been transformed with the development of modernity into an immanent social practice through which humanity takes account of its own impenetrability.... There is no uninterpreted social reality; but nor is there a single coherent 'story' that adequately interprets that reality. Society is the arena of hermeneutic contestation. ${ }^{\text {xxi }}$

The arena of law is frequently discussed in terms of where the realms of the sacred and profane collide. It is here that they converge and contest. It is not only where crime meets justice or where deviance is greeted by punishment but also in the case of the U.S. Supreme Court, where society finds its moral equilibrium. Ethical and moral questions are hermeneutically divined from the template of the Constitution. The Supreme Court Justices can be conceived of as oracles of the age and the Court itself can be considered a type of American Delphi in which the eschatological issues that plague and persist in American society are at least partly resolved. Arbitration by the Supreme Court rests on the critical loyalty to the Constitution. This 'sacred' document acts practically and symbolically as the epistle of the fabric of American nationalistic sentiment and is the essence of the civil religion of state. It is pertinent to note that such arena of institutional contestation that seeks to define the standards of a society should take such a distinctly hermeneutic form just as Ricoeur observed of society in general.

Dilthey and Ricoeur's perception of hermeneutics, with their emphasis on historical understanding and inheritance, is reflected in public regard for constitutional law in the U.S. We see the system of precedent combining with the esteem for the pure and original words of the Framers of the document to produce a brand of hermeneutics not unlike the conventional study of scripture that hastened its development. Christianity operates on the assumption of biblical inerrancy. In that context, hermeneutic anxiousness for accuracy existed in order to precisely convey the letter of that word which is considered infallible: the word of God. A precise analysis of the Constitution is vital as the archetypal canon of law that initiated the nation equally necessitates a precise and accurate interpretation. Supreme Court Justices operate in a sense as custodians of the moral and political standards of the nation and the ultimate scholastic authority on the intentions of the perfected heroes/prophets that forged this key national inheritance. They are the guardians of the political and judicial inheritance of America and the perennial archetype that composes the civil religion of the state. In a nation in which almost everything that is of public interest is televised, including legal proceedings, the Supreme Court remains sacrosanct and immune to the pervasive intrusion of the television camera. It persists as one of the few sacrosanct arenas, beyond this crass invasion and a sacred proceeding in terms of public and 
institutional estimation. The Justices that preside over constitutional law, masterfully interpret its intrinsic meaning and bestow precedent upon subsequent generations as they deem warranted and are seen to be engaged in the holiest of acts within the framework of the civil religion of state. Hermeneutic interpretation in this context is the vital, sacred, observable operation of the state in the perennial tradition of the hallowed and benevolent national ideology. It is, therefore, a definitive component of the civil religion of the nation devoted to deciphering the will of those that founded that nation.

Phillip E. Hammond who co-authored 'Varieties of Civil Religion' with Robert Bellah, explores this same theme in an article entitled 'Constitutional Faith, Legitimating Myth, Civil Religion' that included a review of 'Constitutional Faith' by Constitutional Law Professor Sanford Levinson. ${ }^{\text {xiii }}$ Hammond begins the article by exploring the nature of what he refers to as a 'legitimating myth', the largely agreed upon parameters according to which the nation (any nation) is defined. He points out the fact that such a legitimating myth will be understood differently by different segments of the relevant society. Just as a more basic myth may be understood as allegorical or literal by different elements of a society, the U.S. Constitution also elicits different levels of understanding and engagement. Hammond cites the example of how the Constitution can hang on the wall of a home, unread or not precisely understood but operating nonetheless, as a tacit symbolisation of what the nation represents to an individual citizen. Conversely, the Constitution can be equally as potently symbolic for the Harvard Law Professor who appreciates its intrinsic value on an altogether different level, acutely aware as $s /$ he may be of aspects that $s /$ he finds flawed or imperfect. This communal, legitimating myth appeals on differing levels and facilitates an adherence to the civil religion of the state regardless of a citizen's exact engagement or understanding of the document. Hammond regards the Constitution as more than a simple symbol of the nation. He sees it as a sacred document, vital to a civil religion. It is here that Hammond makes the important distinction between patriotism and civil religion. He concedes that patriotism is something that may be 'created' or constructed. Civil religion on the other hand is a different matter. Hammond says that though patriotism can be 'created', religion, by its very nature must be 'encountered' and he believes that such a contention is as true of civil religion as any conventional religion; "Patriotism is wilful, and individuals can share in it to varying degrees; religion exists, whether or not individuals are aware of it or agree with it." ${ }^{x i v}$ It is in this conception of the fundamental nature of religious adherence or even worship and thinking of it as a phenomenon that is to be 'encountered', that the true spirit of constitutional faith emerges.

It has inherent to it more than the direct symbolisations of the flag or the anthem or the heroic national narratives. It is, of course, much more than a symbolic myth. The Constitution is the ideological and institutional facilitator of the national communion. It is a critical reality of the nation and a tangible continuance of the perennial national ideal. It exists beyond the individual, it is the communal social fact and through that - it elicits the devotion of the individual ${ }^{\mathrm{xx}}$. Hammond describes how the veneration of an object such as the Constitution "...may reflect its role as symbol..." ${ }_{x x v i}$ He qualifies this however by insisting that the communal spirit connected to that symbol must precede the symbolisation. The object is not the foundation for this sense of community, the object emerges as a symbol of that community by virtue of the fact that the sacred can only be 'encountered' and cannot be 'created'. In short, community itself trumps 
symbolic manifestations of that communal group. A final point that Phillip Hammond makes in relation to the Constitution concerns the issue of unity. The consideration of the Constitution as a facilitator of national unity and esprit is slightly ironic in the sense that the Constitution and the Supreme Court are, by their very nature, an object and an arena of contestation and even discord. Hammond confronts this anomaly by pointing to the Constitution as not so much a symbolic something that will unify Americans morally but as "...a vehicle for expressing moral unity" in that country and the agreed upon arbitrator of what morally divides, accentuating the command of national reverence for this secular sacred text. ${ }^{\text {xvii }}$

This assessment of constitutional law combined with the method through which the Supreme Court analyses the cases with which it is presented and the manner in which they arrive at their decision (as outlined in the previous section) reveal a profound devotion to the words of the founders. The semantic dissection, the hermeneutic trawling through the lines of the Constitution, the emphasis on a true and precise interpretation and loyalty to the ones who composed the original draft over two hundred years ago are the hallmark of U.S. Constitutional Law. The lines of the Constitution are sacred and symbolic to the nation of all that is good and right about that nation. The Framers enjoy an aura of secular prophets that bequeathed to the nation a framework for good government and good citizenship as well as a system of what can only be called 'clues' to the path for an equitable, just society and a route to a more satisfactory and idealistic existence. Their genius is institutionally lauded and their words are all but final. In this ground-breaking document, inherited from English Common Law and perfected through a native ingenuity, a righteous path to an existential ideal is illuminated and signals for Americans and, perhaps, humanity in general - the ontological route to (or pretension toward) an earthly imitation of eternal paradise. This secular gospel inspired by a native genius and an actualisation of Enlightenment philosophy, or perhaps for the non-secularist believer, inspired by divine power itself, maps the true course to providence and is perceived as a blueprint for the secular utopia and the perfected, egalitarian homeland. As Supreme Court Justices sift through the sacred conclusions of the Founding Fathers, their task is to divine what is right and just and what is truest to the framework of the Constitution which continuously operates as a template for nationhood.

The Constitution, assuming as it does the trappings of a sacred text along with the institutional reverence for its exact words and an acknowledgement of the genius of those who composed it - has, all in all, an air of the holy. It is, in many ways, irreproachable. It is debated and hermeneutically scrutinized as close to infallible. It is discussed in reverential tones that suggest it is something prized beyond all in the pantheon of national symbols and artefacts. Institutionally, communally and mundanely it contains the distinct trappings of the holy. It is in this hermeneutical odyssey that is the canon of American constitutional case-law and jurisprudence that the Constitution maintains its vitality and relevance. The hermeneutic contestation that, by its very nature, constitutional law ensures - commands attention and devotion as it persists as the living, breathing embodiment of the American ideal. Hermeneutics lends vitality as the sacred text exists as something that is not absolutely definitive but is, rather, a sacred guide and template.

The Constitution is the solid base from which reactions to a world in a state of interminable flux can be reconciled with the core ideal of what America should entail. It 
is from the un-shifting edifice of the Constitution, the unyielding faith in the wisdom of those that composed it and the acknowledgement of the Supreme Court as the ultimate, apolitical arbitrator and interpreters-in-chief of the nation's political inheritance that the definitive, practical implementation of what is right can be imparted. This transpires in accordance with the doctrine of the civil religion of the state and it is through this that the nationalistic ideal of the United States is tended and renewed.

\section{BIBLIOGRAPHY}

Bellah, R. N. "Civil Religion in America”. Journal of the American Academy of Arts and Sciences. Vol. 96, No. 1, (1967). Pg. 1-21.

Billig, M. Banal Nationalism. London: Sage. 1997.

Bork, R. H. The Tempting of America; The Political Seduction of the Law. New York: Touchstone. 1991. Capps, W. H. Religious Studies. Minneapolis: Fortress. 1995.

Dilthey, Wilhelm. Poetry and Experience. Translation, Makkreel, R.A. and Rodi, F., Princeton, New Jersey: Princeton University Press. 1985.

Dilthey, Wilhelm. The Formation of the Historical World in the Human Sciences, Translation, Makkreel, R.A. and Rodi, F., Princeton, New Jersey: Princeton University Press. 2002.

District of Columbia v Heller. 554 U.S. Opinion of the Court. http://www.supremecourt.gov/ opinions/07pdf/07-290.pdf [accessed 10 Mar 2013] 2008.

Durkheim, Emile. The Rules of the Sociological Method Translation: Sollovay, S.\& Mueller J.H., London: Collier-Macmillian. 1966.

Ferguson, Harvie. Phenomenological Sociology. London: Sage. 2006.

Gallup. 2007. “Shrunken Majority Now Favours Stricter Gun Laws”. http://www.gallup.com/poll/ 101731/Shrunken-Majority-Now-Favors-Stricter-Gun-Laws.aspx [accessed 20 Feb 2014]. 2007.

Gallup. 2016. “Guns”. http://www.gallup.com/poll/1645/guns.aspx . [accessed 3 March 2017]. Hammond, Philip. "Constitutional Faith, Legitimating Myth". Civil Religion, Law and Social Enquiry. Vol. 14, No.2. (1989). Pg. 377-391.

Hutchinson, John \& Smith, Anthony D. Nationalism. Oxford: Oxford University Press. 1994.

Lipset, Seymour Martin. American Exceptionalism. New York: Norton. 1997.

Locke, John. Of Civil Government. London: Dent. 1924.

Milbank, Dana. 'Verily these Justices have Gun Laws in their Sights'. The Irish Times. 20 March 2008, available; http://www.irishtimes.com/newspaper/world/ 2008/0320/1205706721320.html[accessed 25 March 2008]. 2008.

Otto, Rudolf. The Idea of the Holy. Translation: Harvey, J.W. Oxford: Oxford University Press. 1958.

Ozkirimli, Umut. Theories of Nationalism. Basingstoke: Macmillan Press. 2000. 
Pew Research. 2016. Gun Rights vs. Gun Control. http://www.people-press.org/2016/08/26/gunrights-vs-gun-control/\#total [accessed 3 March 2017].

Ricouer, Paul. Fallible Man. Translation: Kelbley, Charles. New York: Fordham University Press. 1986.

Ricoeur, Paul. From Text to Action. Translation: Blamey K. \& Thompson, J.B., London: Athlone. 1991.

Scribner, R.W. The German Reformation. Basingstoke: Macmillan Press. 1986.

Smith, Anthony D. Chosen Peoples; Sacred Sources of National Identity. New York: Oxford University Press. 2003.

Smith, Anthony D. National Identity. London: Penguin. 1991.

Toqueville, Alexis de. Democracy in America. Translation: Grant, S., Indianapolis: Hackett. 2000.

United States Centre for Disease Control and Prevention. Death by Firearms Statistics. http:// webapp.cdc.gov/sasweb/ncipc/mortrate10_sy.html [accessed 20 Feb 2014] 2008.

\section{NOTES}

i. U.S. Const., Amend. II. 1791.

ii. United States Centre for Disease Control and Prevention. Firearms. 2008.

iii. Gallup. Guns. 2016 \& Pew Research. 2016.

iv. Tocqueville. Democracy. 106.

v. District of Columbia v Heller. 554 U.S. (2008). 3.

vi. Milbank, Gun Laws. 2008.

vii. District of Columbia v Heller. 554 U.S., 2008: 7

viii. Ibid., 554 U.S. (2008). 11.

ix. Ibid., 12

x. Ibid., 16, 29 \& 31 respectively.

xi. Ibid., 16.

xii. Ibid., 29.

xiii. Ibid., 31.

xiv. Ibid., 18.

xv. Smith. Chosen. 175.

xvi. Billig. Banal.

xvii. Ferguson, Phenomenological. 75.

xviii. Ibid. 75 .

xix. Dithey, Poetry. 35.

xx. Ibid., 59.

xxi. Ricouer. Fallible.

xxii. Ferguson. Phenomenological. 79.

xxiii. Hammond, Constitutional Faith. 1989.

xxiv. Ibid., 380.

xxv. Durkheim. Sociological Method. 7.

xxvi. Hammond, Constitutional Faith. 384.

xxvii. Ibid., 389. 


\section{ABSTRACTS}

This article examines the manner in which constitutional law in the United States serves to preserve, accentuate and institutionalise what Robert Bellah referred to as the 'Civil Religion' of the nation (1967). As the U.S. Supreme Court manages the evolution of the nation, it does so through an institutional deference to the authority of the nation's founders. The United States is not unique in the glorification of the nation's 'Founding Fathers'. It does, however, stand alone in the manner it seeks to maintain a temporal connection with these iconic national figures through the law and the interpretation of that law. U.S. constitutional law seeks to reiterate and reproduce the principles of the Founding Fathers and the ideals that they espoused. This fact is explicated in this article through an examination of the case of the District of Columbia v Heller (2008). This article seeks to account for two key nationalistic phenomena in the United States relating to constitutional law and the U.S. Constitution's infamous Second Amendment. Firstly, the profound institutional reverence for the national heroes that first begat the nation. And, secondly, a precise hermeneutical deference to those Founding Fathers - in law - that is largely unmatched in the developed world.

\section{INDEX}

Keywords: Nationalism, Second Amendment, U.S. Constitution, Hermeneutics, Jurisprudence, Firearms 